\title{
O pensamento integralista de Miguel Reale ${ }^{1}$
}

\author{
Rodrigo Maiolini Rebello Pinho²
}

\section{Resumo:}

Trata-se da análise imanente de um fato doutrinário particular: o ideário integralista de Miguel Reale.

Palavras-chave: Miguel Reale; história do Brasil; ideologia; fascismo; integralismo; crítica.

\section{The ideas and beliefs of Miguel Reale (1932-7)}

\begin{abstract}
:
The objective of this article is to understand the ideas and beliefs of Miguel Reale (1910-2006) from 1932 to 1937, period in which he was a leader of the brazilian right-wing movement Ação Integralista Brasileira.
\end{abstract}

Key words: Miguel Reale; Brazil's history; ideology; Fascism; right-wing; critique.

\begin{abstract}
É preciso colocar o Brasil no problema das Nações!
E nós? O problema brasileiro tem uma incógnita: o Ideal.

(...) o que na Itália representa a ideia de Império e na Alemanha a ideia de Raça, no Brasil se exprime com a ideia de terra.

(...) nosso patriotismo não agride...

Temos tudo em nós mesmos e em nossa casa.

O progresso da técnica, as conquistas da ciência permitem voltar a um regime de vida que parecia destruído pelas cidades tentaculares...

(...) e o homem ouve novamente o chamado da terra fértil.

Vendo as chaminés que se elevam no céu cinzento dos bairros industriais, é imenso o nosso orgulho.

Quando os homens da classe média perdem a sua posição social e econômica, dá-se uma revolução, que pode se processar tanto na linha do desespero bolchevista como no sentido orgânico do Integralismo.
\end{abstract}

\footnotetext{
${ }^{1}$ Parte (modificada) de minha dissertação de mestrado (cf. MAIOLINI REBELO PINHO, 2008). Revisão ortográfico-gramatical de Vânia Noeli Ferreira de Assunção.

2 Mestre, Pontifícia Universidade Católica de São Paulo (PUCC-SP). E-mail: rorpinho@uol.com.br.
} 
Sempre há, para usarmos uma expressão poética de Menotti del Picchia, a sobrevivência das coisas mortas.

Miguel Reale

\section{Introdução}

Miguel Reale (1910-2006) projetou-se como intelectual no interior do movimento integralista. Em outubro de 1932, assim que fundada a Ação Integralista Brasileira (AIB), foi introduzido à sua figura maior: Plínio Salgado (1895-1975). Nesse encontro, verificou que seus "pontos de vista eram na maior parte convergentes". Jovem estudante (ingressara na Faculdade de Direito do Largo São Francisco em 1930), Reale ouviu de Salgado que tinha tudo para se tornar o "jurista do Estado Integral" (REALE, 1987, pp. 72-3).

Dias após, filiou-se aos "camisas-verdes". Com produção teórica intensa, Reale ascendeu rapidamente na hierarquia integralista, ocupando altos postos. Além de membro do "triunvirato" do Conselho Supremo da AIB (órgão máximo, composto, hierarquicamente, por Plínio Salgado, Gustavo Barroso e Reale), ocupou o cargo de secretário nacional de doutrina, dirigiu a Revista Panorama e o jornal Acção. Gabava-se da sugestão do sigma $(\Sigma)$ como símbolo oficial da organização (REALE, 1987, p. 85).

O que aqui nos importa, todavia, não é o relato dos fatos de sua experiência integralista, mas sim a compreensão dos principais aspectos de sua produção teórica no período de 1932 a 1937. É a ela que nos ateremos. Com esse propósito, analisaremos, de modo imanente, as obras que produziu no quinquênio de duração da AIB, quando lançou as bases de seu pensamento 3 .

Fica o leitor avisado de que a matéria será tratada em tempo verbal presente. Maneira de pôr diante dos olhos os movimentos de pensamento analisados, como se os tivesse diante de si ditos pelo próprio Miguel Reale, cujas palavras, pois, medeiam esta reconstituição. Desobrigo-me assim do emprego equívoco do futuro do pretérito, bem como evito expressões como "segundo Reale", "entende Reale", como se a todo momento necessitasse

\footnotetext{
3 Os seguintes livros e artigos foram analisados: A crise da liberdade (1931- incorporado em $O$ estado moderno), $O$ estado moderno: liberalismo, fascismo, integralismo (1934), Formação da política burguesa: introdução ao estado moderno (1934), $A B C$ do integralismo (1935), O capitalismo internacional: introdução à economia nova (1935), Perspectivas integralistas (1935), Nós e os fascistas da Europa (1936), Corporativismo e unidade nacional (1936), Atualidades de um mundo antigo (1936), Atualidades brasileiras (1937), Integralismo e democracia (1937). A edição de regra empregada foi a das Obras políticas: $1^{\text {a }}$ fase $-1931 / 1937$, de 1983. Utilizaram-se, também, edições de época de $O$ estado moderno: liberalismo, fascismo, integralismo e de Perspectivas integralistas.
} 
pontuar que quem diz é Miguel Reale e que com o que ele diz não se transige. Fica desde já posta a radical intransigência, em qualquer modo ou tempo, com o pensamento realiano. Precisamente por isso, pretende-se expô-lo de modo fidedigno, a fim de que, ao final, una-se no leitor o páthos da indignação à orientação do conhecimento.

Passo, então, à análise imanente 4 do integralismo de Miguel Reale5.

\section{A concepção integral da história}

Há pois que considerar no estudo da história dois aspectos do real, mediante leis de duas naturezas; as leis de causa eficiente, $e$ as leis finais, referentes respectivamente aos fatos, às ideias e à vontade, ao determinismo do mundo objetivo e à liberdade do espírito: ao costume e à lei; à sociedade e ao estado, para exemplificar no campo da política.

Miguel Reale

Reale supõe-se criador de uma nova "concepção de história”. A sua criatura nomeia de concepção integral da história ou historiografia integral ou método integral.

A integralidade, seu atributo central, define-se por contraposição a concepções que tratam a história de forma parcial, unilateral. Integral, pois considera o processo histórico em sua totalidade ${ }^{6}$.

Considerar o processo histórico em sua totalidade significa afirmar que é composto de duas partes: a do ser e a do dever-ser.

A parte do ser é o mundo objetivo, das coisas, é o reino da natureza, dos "fatos brutos extraespirituais" ou, como mais frequentemente diz, das causas eficientes. O dever-ser, por sua vez, é a dimensão da subjetividade,

4 Trata-se, aqui, de investigar um "fato doutrinário", isto é: "a constelação global do pensamento de um autor, ou uma parte desse mesmo conjunto. É simples designativo de uma dada entidade de pensamento, podendo ser usado para indicar qualquer manifestação de pensamento explicitamente oferecida. Com ela queremos simplesmente indicar um objeto que tem nos textos a sua expressão objetiva”. A investigação dar-se-á pela via da "análise imanente", a qual considera os "fatos ideológicos" (ou fatos doutrinários) "entidades específicas, com características próprias em cada caso, que cabe descrever numa investigação concreta que respeite a trama interna de suas articulações, de modo que fique revelado objetivamente seu perfil de conteúdos e a forma pela qual eles se estruturam e afirmam" (CHASIN, 1978, pp. 60; 77).

5 Como se vê, o propósito não é realizar uma revisão da bibliografia sobre o integralismo de Miguel Reale. Aos interessados na empreitada, há, dentre outros: Araújo (1988); Melo (1994); Maiolini Rebello Pinho (2008); Pinheiro Ramos (2008); Bertonha (2013); RODRIGUES (2014); Dias Tanagino, (2018). Saliento que as divergências fundamentais sobre o integralismo em geral, tais quais adequadamente expostas por Rago (2008), subsistem, com as nuances, claro, próprias dos tempos e dos autores.

6 Nesse sentido, Reale dispõe que "A verdade está na integração das observações particulares da realidade concreta" e, contrapondo-se ao "medíocre "materialismo histórico' que apresenta a sociedade como uma superestrutura da economia, da raça ou do meio físico", clama: "façamos a história do homem na inteira complexidade de seus fatores múltiplos" (REALE, 1983-1, pp. 31-2). 
da liberdade, da consciência, do espírito ou das causas finais. As leis do primeiro são causais e indiferentes, ao passo que o segundo é regido por leis finais (teleológicas) e éticas.

A novidade da historiografia integral é congregar em uma mesma concepção as dimensões do ser e do dever-ser, concebendo a história como união desses dois momentos (dimensões, partes):

Há uma ciência do espírito e da liberdade que aprecia os fatos e os atos segundo o dever-ser; e há uma ciência da Natureza e do determinismo que é a do mundo do ser. Elas não são antagônicas, não se excluem. Elas se completam e se influenciam reciprocamente, mas uma não pode ser reduzida à outra, como fazem os materialistas de um lado, os idealistas em campo oposto. É o vício do unilateralismo que faz um Marx só ver a economia, ou um Ratzel só ver a geografia... (REALE, 1983-1, p. 28)

Não há, pois, antítese entre o mundo do ser e do dever-ser, entre o reino da Natureza e da liberdade (REALE, 1934, p. 47).

Qualifica-se como unilateral (ou parcial) uma concepção de história que concede uma posição dominante ou exclusiva a um desses "dois mundos distintos, o das coisas e o do homem, o da necessidade e o da liberdade, o da inconsciência e o da consciência, o do ser e o do dever-ser" (REALE, 1983-1, p. 195). É o equívoco, de um lado, do naturalismo (ou materialismo ou determinismo, em que reina o ser) e, de outro, do idealismo (reina o dever-ser). É pela via da crítica dessas concepções parciais, do idealismo e - principalmente - do naturalismo, que se estrutura a concepção integral da história.

Sobre os idealistas, limita-se a dizer que "sacrificam o objeto, as coisas" (a dimensão do ser).

Já o erro do naturalismo recebe maior atenção, visto que é “o grande equívoco de uma civilização", pois opera "a redução do homem às coisas, da história à história natural” (REALE, 1983-1, p. 197). Os naturalistas (materialistas ou deterministas) "sacrificam o sujeito, o homem, os valores autônomos do espírito", a dimensão do dever-ser (REALE, 1983-1, p. 32). O naturalismo se atém com exclusividade às causas eficientes, uma causalidade independente do "fator humano", da liberdade, do "poder de querer e de agir", isto é, sem finalidade ou teleologia. Ao conceber a história como regida apenas por leis de causa eficiente, o naturalismo expulsa a liberdade humana (a teleologia, o deverser, a liberdade, o espírito e, inclusive, o estado) e reduz o homem às coisas, a história à história natural:

Desde que o determinismo penetra na história e expulsa o finalismo, dela sai o homem, porque se lhe rouba a liberdade, a autonomia, poder de querer e de agir (...). O fim é transferido, em última análise, do homem para as coisas, para o próprio jogo dos processos naturais. As leis causais perdem o caráter 
indiferente para adquirir um fundo ético (...). Estranha situação! Todo o teleologismo desaparece porque a Natureza é o reino dos fins, e os homens não passam de seus devotados servos: o mundo do ser absorve o mundo do dever-ser. (REALE, 1934, p. 14)

Se da história é feita história natural, se "o mundo do ser absorve o mundo do dever-ser", o homem torna-se servo da natureza, a liberdade é dominada pela necessidade, a consciência pela inconsciência (e, também, o estado pela sociedade). O que se qualifica como uma "estranha situação" é que a explicação naturalista não implica a supressão dos fins, mas sim sua subtração e transferência do homem para a natureza, no sentido de que, por essa teoria, o homem não é regente da natureza, mas sim regido por ela.

O naturalismo, esse "grande equívoco de uma civilização", é a "premissa burguesa" cujo "peso morto" os integralistas devem largar abandonando as explicações exclusivamente causais e o governo das coisas (da natureza, dos apetites, da sociedade), dos quais resultam tanto o liberalismo quanto o marxismo; e afirmando o espiritualismo e o governo dos fins (dos homens, da consciência, do estado).

Abandonando o naturalismo,

os movimentos integralistas deixam o peso morto da premissa burguesa (o naturalismo), marcando o ritmo espiritualista dos novos tempos pela reafirmação do princípio da finalidade como complemento do de causalidade (REALE, 1983-1, p. 198).

Assim, Reale defende a ideia de que se busque "o ritmo espiritualista dos novos tempos" (o ritmo do estado, do dever-ser, da consciência), abandonando a "premissa maior da cultura burguesa", o naturalismo, que teria no "liberalismo" e no "marxismo" seus representantes principais. O integralismo é uma reação espiritual ao utilitarismo burguês e ao materialismo marxista, pois afirma o "princípio da finalidade como complemento do de causalidade" contra ambos pautados que são pela exclusão do "princípio da finalidade", pelo caráter "antiteleológico"7.

Politicamente, pode-se dizer a reação espiritual como o transitar de uma sociedade regida pelo afinalismo do "governo das coisas" (pelo "anomismo dos fins singulares") para uma organização social pautada pelo "fator humano", isto é: regida de forma teleológica, segundo um ideal comum, pelo estado. Portanto, nessa trama, o estado tem a função de instrumento político da reação espiritual integralista.

Ora, se (i) o princípio da finalidade complementa o da causalidade no sentido de que "O homem se serve dos conhecimentos obtidos no

7 "[Marx] revela a atitude mental própria da cultura burguesa, racionalista e antiteleológica" (REALE, 1983-2, p. 236). 
determinismo do mundo objetivo para realizar os fins que a sua subjetividade livremente estabelece" (REALE, 1983-1, p. 28); se (ii) o Estado está entre as espécies governadas por leis finais (junto do homem, das ideias, da vontade, da lei, da liberdade do espírito) e a sociedade está entre as espécies governadas por leis causais (junto da natureza, do costume, dos fatos, do mundo objetivo) ${ }^{8}$; logo, no plano político, o estado se serve do conhecimento das leis naturais da sociedade para impor um dever-ser para ela.

Isso fica nítido quando Reale classifica os aspectos do real como espécies regidas por leis causais e leis finais, assim dispondo:

Há pois que considerar no estudo da história dois aspectos do real, mediante leis de duas naturezas; as leis de causa eficiente, e as leis finais, referentes respectivamente aos fatos, às ideias e à vontade, ao determinismo do mundo objetivo e à liberdade do espírito: ao costume e à lei; à sociedade e ao estado, para exemplificar no campo da política. (REALE, 1983-1, p. 28)

A sociedade (assim como os fatos, os costumes, o determinismo do mundo objetivo e a natureza) no pedaço do ser; o estado (assim como as ideias, a vontade, à liberdade do espírito, as leis e o homem) no pedaço do dever-ser. Logo, no determinismo do mundo objetivo, pautado pela causalidade cega, a presença da sociedade. No plano das ideias e da vontade, a presença do estado, do "fator humano", do "sujeito", da "liberdade do espírito", que tem a sociedade por natural objeto - alvo de seu conhecimento e de sua ação finalística9.

Daí que o "revolucionarismo integralista"

brota da consciência do dever que tem o estado de se servir dos conhecimentos das leis naturais da sociedade para garantir a esta uma justiça cada vez maior e uma riqueza cada vez mais proporcionada (REALE, 1983-1, p. 226).

O estado é, portanto, o meio necessário da reação espiritual propalada pelo integralismo, visto que - veremos no tópico seguinte -, deixada por sua própria conta, impera na sociedade o livre jogo das forças naturais e vigora a lei do mais forte (REALE, 1983-2, p. 273). O estado expressão do fator humano, da consciência, da liberdade - realiza o ideal comum (dever-ser) da nação por meio de seu agir finalístico sobre a sociedade - expressão das coisas, da inconsciência, da necessidade, dos interesses, da anomia dos fins singulares.

8 Nesse sentido: "Baseamo-nos nas conquistas realizadas mediante o pressuposto determinista para realizarmos fins que livremente fixamos. Não há, pois, antítese entre o mundo do ser e do dever-ser, entre o reino da Natureza e da Liberdade." (REALE, 1934, p. 47)

9 "O estadista moderno deve falar a milhões de homens, descer até ao coração da massa, transferindo-lhe a consciência de um destino através de sua palavra quente, firme, clara, incisiva, simples e sincera." (REALE, 1983-1, p. 73-74, grifo meu) 
Como vemos, o naturalismo não vigora tão somente no plano teórico, não vigora apenas como uma concepção. Aliás, a vigência do naturalismo enquanto explicação para a vida social é um reflexo da realidade vivida, do naturalismo em ato, é uma reafirmação, na teoria, do estágio histórico do domínio burguês, instaurado pela Revolução Francesa e em curso. Período marcado pelo efetivo governo das coisas, pelo afinalismo da vida social, em suma, pelo naturalismo operante.

Mais que um embate contra uma concepção, Reale almeja um embate contra um certo estado de coisas. O naturalismo operante se põe na forma de uma sociedade anômica, que tem por condição o caráter inerte (negativo) do estado liberal. Reage-se contra esse estado posto pela implantação do revolucionário estado integral, forma de estado apta a impor uma finalidade para a vida natural e anômica da sociedade liberal.

Pode-se dizer tanto que a historiografia integral é a expressão (em termos de concepção de história) da defesa da reação espiritual por meio do estado integral, quanto que a reação espiritual do estado integral é a expressão, em termos políticos, da concepção integral da história.

Em resumo, ao naturalismo enquanto concepção de história, Reale opõe a concepção integral da história. Ao naturalismo em ato (propriamente: a sociedade e o estado liberais), Reale opõe a reação espiritual operada pelo estado integral.

A suma é a seguinte:

O liberalismo é essencialmente naturalista (...). O liberalismo continuou no marxismo a sua marcha para a destruição do estado. / O determinismo do mundo físico foi transportado para o mundo social. $\mathrm{O}$ homem foi considerado um simples joguete dos acontecimentos, incapaz de reagir para a realização de um fim. Era a civilização antifinalista que se iniciava (...). E essa doutrina denominou-se pomposamente de "liberalismo"! Liberdade dentro do mais ferrenho dos determinismos, o imposto pela exigência dos apetites. (REALE, 1983-3, pp. 94-5)

Como vimos, só se pode "reagir para a realização de um fim", libertando-se da "civilização antifinalista", através do estado integral. É deste que passamos a tratar.

\section{O estado integral}

Até a luta de classe é uma criação do governo.

Miguel Reale

Elaborado também por oposição, o estado integral tem por contraponto o estado liberal, cuja nota principal é o abstencionismo econômico. Trata-se de um estado de conduta negativa, cujos poderes são 
contidos diante do indivíduo, de um estado que atua apenas para preservar os direitos naturais e garantir a igualdade formal perante a lei. É o estado mínimo, o estado como mal necessário, o estado do laissez-faire da doutrina liberal.

O cerne da crítica realiana ao estado liberal é que ele não regulamentou a vida econômica:

O estado liberal - o liberalismo é a consagração sistemática da indiferença do estado para com a vida social e econômica, a limitação da ação governamental às funções de ordem jurídica. Diante do estado só há o cidadão, sujeito de direitos políticos, submetido às mais variadas restrições legais: o direito é monopólio do estado enquanto a economia é monopólio do indivíduo (...). A história política do século passado e a de nossos dias resultam desse equívoco inicial da regulamentação da vida jurídica e da não regulamentação da vida econômica. (REALE, 1983-3, p. 58)

"Desse equívoco inicial” resulta a "crise da política moderna", com o fortalecimento dos poderes do indivíduo e o enfraquecimento dos poderes do estado (REALE, 1983-1, p. 70). Limitado ao exercício de funções jurídicas e apeado de seu posto de "centro coordenador e orientador das energias individuais”, o estado liberal deixa a economia nas mãos dos indivíduos, acarretando, como antes apontamos, o naturalismo vivido, isto é, o governo das coisas: a vigência da cobiça, da ganância, dos apetites, do predomínio do mais forte sobre o mais fraco, da luta de classes, do “espírito judaico"10 (REALE, 1934, pp. 175; 208).

Reale, então, investe contra essa economia dominada por interesses individuais, por faculdades de agir sem correspondentes deveres de agir:

A teoria da sanção automática resultante do espontâneo jogo das forças produtivas foi uma série de atos de devoção prestados perante o altar da deusa Natureza. Hoje, quando o desassossego invadiu todos os corações, quando, após falar "papá" e "mamã", a criança aprende a palavra "crise" há ainda quem acredite no providencialismo benéfico da natureza? / Por que existe toda essa angústia universal? Porque o estado liberal garantiu, no campo econômico, a "facultas agendi", mas se esqueceu de estabelecer a "norma agendi". / A economia separou-se do direito, e o direito insubordinou-se à moral. (REALE, 1983-2, p. 272)

Logo, "a causa dos males da sociedade burguesa" (REALE, 1983-2, p. 272) é que a economia dissociou-se do direito, da moral, do estado. $\mathrm{Na}$ ausência de um estado diretor e organizador da vida social, os indivíduos visam apenas a seus propósitos particulares, seu benefício egoístico, o que interdita a realização de uma moral posta pelo estado.

${ }^{10}$ Acerca da natureza específica do antissemitismo no integralismo (distinto do "conteúdo biológico da concepção rácica do nazismo”), veja-se Rago (2008, p. 214). 
Isso porque "o equilíbrio não pode, de modo algum, ser estabelecido espontaneamente entre as forças sociais, sem que haja unidade moral de coordenação e direção" (REALE, 1934, p. 157).

Critica-se então o liberalismo por sua crença na "harmonia automática dos interesses individuais" ou no "equilíbrio automático dos egoísmos". O absenteísmo do estado liberal, a ausência de "uma unidade moral de coordenação e direção", libera o antagonismo entre as classes. Nesse quadro, prega-se que o estado, na função de agente do bem comum, promova a conciliação de classes, o equilíbrio entre fracos e fortes, pois:

O antagonismo das classes só existe nas sociedades que permitem, ao lado do poder político organizado, a anarquia das forças econômicas (...). Hoje em dia, o estado precisa estar acima das classes. (REALE, 1934, p. 175)

Vê-se que "um dos princípios fundamentais do integralismo é a colaboração das classes, e não a luta de classes pregada pelo comunismo" (REALE, 1983-3, p. 201). Reale defende a solidariedade das classes no âmbito nacional, viabilizada pelo "nacionalismo orgânico", isto é, pela integração de todas as forças sociais na estrutura corporativa do estado integral ${ }^{11}$.

Afinal, o estado integral "não representa uma classe, mas a totalidade das classes" (REALE, 1983-2, p. 273) e, nessa condição, está acima delas:

o estado integral não é o estado subordinado à economia, mas sim o estado supereconômico, que está acima da economia, não como produtor, mas como orientador e fiscalizador (REALE, 1983-3, p. 202).

\section{O nacionalismo anticapitalista}

(...) as nações e os estados são vítimas do capitalismo que os arrasta a guerras imperialistas.

Defender a nação significa combater violentamente o capitalismo. Nacionalismo sem anticapitalismo é expressão vazia, motivo poético de política "dilettante" (...). A luta anticapitalista deve se travar nos quadros das nações.

(...) o fim político do integralismo é a identificação do estado com o povo, do estado com a nação.

Miguel Reale

11 Sobre a estrutura interna do estado integral proposta por Reale, veja-se a minha dissertação de mestrado (PINHO, 2008, pp. 70-1). 
Além de ceder terreno à luta de classes, o abstencionismo do estado liberal permite que bancos e agiotas internacionais (o denominado "superestado-transnacional-capitalista") dominem o estado por dentro, suguem sua soberania e determinem sua economia (REALE, 1934, pp. 1212), subjugando igualmente todas as "forças nacionais", tanto capital como trabalho (o que é o traço distintivo do capitalismo coevo). Trata-se de uma época de domínio do capital financeiro, personificado em banqueiros e agiotas sem pátria que, pelo controle da moeda, escravizam todos os estados e as suas forças nacionais. É o que o pensador integralista dispõe a seguir:

\begin{abstract}
Os bancos estabelecem-se nos organismos nacionais, controlam as economias, impõem a sua vontade aos produtores e agricultores, aos comerciantes e aos operários. O estado, hipotecado em uma longa série de empréstimos, é um simples empregado do estado super-nacional-capitalista, cujos primeiros ministros são quase todos da raça judaica (...). Só os liberais acreditam na soberania do povo brasileiro... (REALE, 1934, p. 122)
\end{abstract}

Dessa maneira, o "supercapitalismo" instrumentaliza os estados nacionais para seus propósitos, fazendo queesses entes - potencialmente portadores do ideal comum nacional - atuem contra a nação. O controle da moeda é o meio concreto pelo qual essa instrumentalização efetua-se. Daí que a ruptura do laço de submissão do estado ao "supercapitalismo" exige a "nacionalização de todo o sistema creditório" e a revisão da dívida externa. Com isso, os bancos (nacionalizados) exerceriam apenas a função de abastecer o mercado dos meios de troca necessários e teriam sua atuação orientada pelo bem comum, pelo interesse comum da coletividade nacional.

Em síntese, o "banqueirismo internacional" e os "agiotas" aproveitam-se da negatividade do estado liberal para assumir, ao redor do mundo, o controle dos estados nacionais. Os estados perdem sua soberania, pois, em vez de desempenharem o papel de promotores do bem comum da nação, por meio da prescrição de um dever-ser (uma moral) à economia, permitem que toda ela passe a ser determinada pelos interesses imediatistas das finanças internacionais. Com essa visão, Reale afirma que a "luta imediata é contra o capitalismo financeiro" e o correspondente "espírito judaico de açambarcamento monetário".

Investindo contra essa situação, Reale desfralda a bandeira do nacionalismo anticapitalista ${ }^{12}$. Vejamos o que significam, no léxico realiano, essas categorias: "nacionalismo" e "anticapitalismo".

12 "Defender a nação significa combater violentamente o capitalismo. Nacionalismo sem anticapitalismo é expressão vazia, motivo poético de política 'dilettante' (...). A luta anticapitalista deve se travar nos quadros das nações.” (REALE, 1934, p. 123). 
Capitalismo, segundo entende, é o sistema caracterizado pela separação entre economia e moral, em que os particulares buscam ampliar desregradamente seus ganhos econômicos, sem atender a interesses comuns ${ }^{13}$. O capitalismo, diz, não é caracterizado pela propriedade privada $^{14}$, mas pela insubmissão do movimento econômico à moral (ao ideal comum), que deve se concretizar no agir estatal. O capitalismo financeiro é a forma coetânea dessa insubmissão, do governo das coisas, da civilização burguesa antifinalista. É a ela que se opõe o "revolucionarismo integralista", na medida em que pretende impor um dever-ser político à vida econômica. Explica-se, assim, que Reale utilize a expressão anticapitalismo em um sentido geral (defesa da subordinação da economia a um ideal comum) e em um específico (crítica ao "agiotarismo" e ao capitalismo financeiro).

Ao anticapitalismo agrega-se o nacionalismo. Agrega-se porque a nação é um "ideal comum”, é “a síntese das aspirações coletivas”, é a "consciência comum de querer" de um povo e o estado integral (ao contrário da negatividade do estado liberal), é um estado ético, finalístico, que dirige a sociedade e tem a missão de realizar o "ideal comum", ao qual deve se subordinar a economia do país. Daí que Reale professe que "o fim político do integralismo é a identificação do estado com a nação”.

Essa identificação não é material nem quantitativa, mas sim espiritual e qualitativa. A nação não é um palco de interesses, mas uma síntese das aspirações coletivas. $O$ estado não se identifica quantitativamente, por "força numérica", com a nação, mas qualitativamente, "no sentido de exprimir seus valores mais altos"15. Isso se dá por intermédio de uma "elite", "intérprete da vontade coletiva" ("as afirmações, as aspirações e os valores mais altos e mais representativos da vida nacional"), que dirige a "causa pública" e "traça (...) o destino dos povos e das nações” (REALE, 1983-2, p. 253).

O ideal ao qual deve se submeter a economia é o ideal comum nacional. O nacionalismo é a defesa da realização do ideal comum de cada nação pelo estado. E realizar um tal ideal comum é, exatamente, impor à economia uma finalidade, assim extirpando o governo das coisas, a vida causal.

13 Veja-se, por exemplo, Reale (1983-2, pp. 224-5).

14 Se assim fosse, "forçoso seria reconhecer no capitalismo um fato universal. Não haveria época não-capitalista, a não ser nas mais remotas fases da evolução social" (REALE, 1983-2, p. 194). Reale entende, aliás, que se deve defender a propriedade privada contra $o$ capitalismo, no sentido de que ele acarreta a concentração de capitais (REALE, 1983-2, p. 236).

${ }_{15}$ "O estado é, pois, um organismo complexo de forma jurídica, mas de conteúdo políticohistórico, tendente a se identificar com a nação, não materialmente no sentido de absorver os indivíduos e os grupos, mas espiritualmente no sentido de exprimir seus valores mais altos./ O estado exprime qualitativa e não quantitativamente a nação.” (REALE, 1983-2, p. 134) 
Trata-se, assim, do "reerguimento das pátrias contra o capitalismo", o que confere "uma extensão muito maior à revolução, que deixou de ser de uma classe, para se transformar no movimento da nação inteira" (REALE, 1983-3, p. 209). A revolução é comandada pela classe média (veremos adiante), mas em nome da nação inteira, já que todas as forças sociais são vítimas do capitalismo, que é inimigo da nação.

Eis o conteúdo do "nacionalismo anticapitalista".

\section{O ideal desconhecido}

E nós? O problema brasileiro tem uma incógnita: o ideal.

Um povo torna-se nação quando se analisa interiormente $e$ recebe do passado a consciência de um papel na história. Só quando um povo formula um ideal dizendo: Quero ser isto!, só então é que a pátria é nação e a nação se faz estado.

Miguel Reale

Como vimos, para subordinar a anarquia econômica a um dever-ser político e libertar o estado das mãos do capital financeiro, óbice da unidade espiritual entre nação e estado, é necessário, primeiro, que venha à luz a nação (o estado já se tem), isto é: "uma consciência comum de querer”. É a consciência de um ideal nacional, de um ideal comum, que faz de um povo uma nação, cujos propósitos devem ser encarnados pelo estado em seu agir teleológico.

O problema é que no Brasil ainda não há uma nação. Aqui "faltava uma consciência comum de querer" (REALE, 1934, p. 127), a "consciência de um ideal nacional", a "consciência de um ideal comum", por isso "não conseguimos ser nação". Somos povo (e estado), distingue, sem sermos nação:

Nossa política é de oportunismo porque nos falta a consciência de um ideal nacional. Somente quando um povo adquire consciência de um ideal comum é que esse povo sobe mais um degrau e se transforma em nação. (REALE, 1983-3, p. 169)

O povo brasileiro não subiu o degrau que o alçaria ao status de nação. Isso foi resultado histórico da passividade diante da extensão do território nacional: sem limites fornecidos por um estado forte, "o homem do Brasil" foi se espalhando pelo território de modo desregrado. Por isso, "temos vivido na admiração passiva das magnificências da nossa natureza”.

Recorrendo a Plínio Salgado, seu chefe na Ação Integralista Brasileira, Reale apresenta uma explicação histórica dessa falta decisiva:

"O nosso senso da liberdade, escreve Plínio Salgado, (...) vinha da própria lição das distâncias geográficas. Dispondo de um 
continente inteiro, o homem do Brasil sentia a necessidade de locomover-se para onde quisesse, em que direção entendesse". Não havia uma liberdade a conquistar, como na Europa: aqui, ao contrário, havia um conjunto de deveres a criar, pois a liberdade era ilimitada e se realizava sem esforço na ampliação da terra virgem. (REALE, 1934, p. 128)

Assim, na ausência de direção, de estado, as vastas distâncias geográficas engendraram um senso de liberdade ilimitada, de faculdades desacompanhadas de deveres comuns. Essa condição "exigia autoridade, governo com finalidades firmes para criar nas populações brasileiras o hábito da vida associativa” (REALE, 1934, p. 127), o que, contudo, não ocorreu.

O Brasil fez-se estado antes de se fazer nação porque nunca constituiu um ideal comum e:

As nações são como os indivíduos. Perdem-se quando um ideal não limita as suas energias, não coordena as suas forças múltiplas. Em 400 anos os brasileiros não conceberam um grande sonho... (REALE, 1934, p. 129)

Essa lacuna é uma especificidade da situação brasileira e coloca o Brasil um passo atrás dos "nacionalistas" europeus, como vemos no trecho a seguir, em que Reale promove uma comparação com a Itália:

$\mathrm{Na}$ Itália, os nacionalistas se impuseram a imensa tarefa de reviver as glórias do passado, no esplendor da disciplina das gerações novas. No Brasil a tarefa é mais árdua. Trata-se de revelar uma nação, cuja palavra ainda não se fez ouvir, cujos valores espirituais o mundo desconhece e não poucos brasileiros ignoram. (REALE, 1983-3, p. 229)

Por essa razão, o problema brasileiro é antes de tudo "moral” - é preciso revelar um "ideal comum", um "grande sonho", sinalizando o dever-ser político da revolução integralista:

Mais alto que os problemas econômicos-políticos, é o problema moral da nossa cultura. A Alemanha alimenta o sonho poderoso da raça; a Itália, o sonho maravilhoso do império; a Inglaterra estende o olhar pela vastidão dos mercados e das conquistas; a América do Norte empenha-se na organização para o domínio da máquina; a Rússia se embuça no sacrifício proletário; e a França já se agita para reafirmar seus valores mais altos. E nós? O problema brasileiro tem uma incógnita: o ideal. Temos vivido sem ele, na admiração passiva das magnificências da nossa natureza. Temos nos contentado com os sucedâneos das revoluções improvisadas. Se, alhures, grandes revoluções se fizeram sem um programa inicial determinado, a nossa deve começar, ao contrário, revelando um rumo. (REALE, 1934, p. 242)

Assim, se o ideal comum da Alemanha é a raça; da Itália, o império; da Inglaterra, a expansão do mercado; dos Estados Unidos da América, a 
máquina; se a França, se até a Rússia ostenta uma consciência comum, aqui a questão central é "E nós? O problema brasileiro tem uma incógnita: o ideal" (REALE, 1934, p.242). Trata-se de responder a essa incógnita, de descobrir o ideal típico da terra brasileira, ideal que, sendo o alicerce da unidade nacional, deve ser realizado pelo estado.

Operando um paralelismo forçado com a Antiguidade grega, Reale aborda o significado dessa incógnita e, logo, do problema brasileiro:

Faltou um centro de referência à história grega, faltou a consciência comum de um dever, faltou o imperativo comum de um ideal. A Grécia não chegou a ser estado-nação porque não teve um ideal comum, nada quis em comum: cada grupo quis para si, cada qual quis ser o centro sem perceber que o centro das nacionalidades está nos recíprocos reconhecimentos dos direitos e dos deveres, das virtudes e dos vícios. Foi por esse motivo, pensando no triste fim da história grega que terminei $O$ estado moderno proclamando que o "problema brasileiro tem uma incógnita: o ideal”. Alguns acharam curiosa essa afirmação, outros demasiadamente vaga. Aqui se compreende melhor o que quero dizer. Um povo torna-se nação quando se analisa interiormente e recebe do passado a consciência de um papel na história. Só quando um povo formula um ideal dizendo: Quero ser isto!, só então é que a pátria é nação e a nação se faz estado. No fundo, o que é a nação se não uma consciência comum de querer, e que é a soberania do estado, senão o que diz Gerber, "o poder de querer em um moral organismo concebido como pessoa”? Só onde há consciência de fins comuns há soberania; só onde há soberania há estado. Não nos iludamos. Não basta possuir grandes vultos no passado para que se forme uma consciência nacional. Não bastam também estradas de ferro, rodovias, linhas aéreas, rádios, telégrafos, comércio interno. Não bastam a força e a glória dos exércitos e das esquadras. Não basta a unidade da língua e a semelhança das religiões. Não basta o esplendor das indústrias e as afirmações maravilhosas da ciência. Não bastam as divinas criações da arte. Consciência nacional existe onde há esses fatores todos e outros mais, desde que de geração em geração se transmita o culto dos grandes homens, o orgulho pelo que se fez e a certeza de que é possível fazer mais. Consciência nacional existe onde há memória, presença do passado como estímulo do presente, ou seja, a unidade da tradição. (REALE, 1983-1, p. 81)

Nesse longo trecho, Reale diz, uma vez mais, que uma nação não se constitui materialmente, mas sim espiritualmente, até porque é, ela própria, um ideal, uma consciência. A trama do tecido nacional não é feita de estradas de ferro, rodovias, linhas aéreas, rádios, telégrafos, comércio interno, armas, língua, religiões, indústrias, ciência, arte, grandes personagens etc. Nada disso cimenta uma nação, mas sim a "consciência comum de um querer", o "imperativo comum de um ideal”, a "consciência nacional”. 
O encontro com essa consciência nacional não é com algo novo; é um reencontro com o passado. Deve-se lançar os olhos ao passado para de lá receber a "consciência nacional”, para receber a consciência de um papel na história, o que permitirá então exclamar o revelado: “Quero ser isto!”. O ideal comum, o dever-ser a nortear o estado no presente é, pois, um legado do passado. A força da memória garante que o passado possa sempre atualizar-se no presente, tornando possível que se veja na história a continuidade de uma tradição. Por isso, Reale dispõe: "Consciência nacional existe onde há memória, presença do passado como estímulo do presente, ou seja, a unidade da tradição".

Trata-se, enfim, da "sobrevivência das coisas mortas" (REALE, 1983-1, p. 130).

\section{O ideal revelado: o bandeirismo}

(...) a grandeza do integralismo consiste em ter revivido o antigo ideal da nação, conclamando os novos bandeirantes para a conquista da terra e de nós mesmos. É o imperialismo dentro das fronteiras. (...) e o homem ouve novamente o chamado da terra fértil.

o liberalismo no Brasil foi um ato de passividade ante as forças da terra, um desvio do bandeirismo que é a reação permanente do homem contra as forças da natureza.

Miguel Reale

Nesse movimento de regresso, de volta ao passado, Reale encontra na terra vasta e em suas potencialidades o eixo da história nacional, e no ideal bandeirante, a consciência do fim comum, o télos integralista: a conquista da própria terra. Assim, a terra: o eixo da história brasileira; sua conquista (o ideal bandeirante): "nossa" consciência comum de querer e "nosso" papel na história.

É o que sustenta a seguir, num artigo sobre a obra Geografia sentimental, de Plínio Salgado:

O espaço é a constante do livro de Plínio Salgado. Pode-se mesmo dizer que estamos apreciando uma visão ética e histórica da pátria através da geografia./ A propósito de tudo, surge o espaço, como realidade primeira e dado fundamental. Há em todas as páginas uma lição sociológica pondo em evidência o fator terra. Se fôssemos dados a exageros e unilateralidades, diríamos que o que na Itália representa a ideia de império e na Alemanha a ideia de raça, no Brasil se exprime com a ideia de terra. A terra, as características mesológicas, o patrimônio cultural que nossos avós nos legaram, é como que o eixo de nossa história e de nossa alma de povo. Nossas epopeias 
são ainda as da conquista direta ou indireta da terra, as das bandeiras, as das entradas, as dos criadores nordestinos, as dos plantadores de fazendas, as dos desbravadores do sertão. (REALE, 1983-3, p. 149)

O "eixo de nossa história e de nossa alma de povo" é o "fator terra", "o espaço como realidade primeira e dado fundamental", "as características mesológicas, o patrimônio cultural que nossos avós nos legaram”. Tanto é a terra o fator que define o Brasil como nação que "nossos" grandes feitos passados são "ainda" os atos voltados à sua conquista, isto é, as bandeiras, as entradas, as realizações dos criadores nordestinos, dos plantadores de fazendas, dos desbravadores do sertão.

A terra é o eixo de nossa história, logo, sua conquista é o dever-ser nacional. Isto é, a natureza e o espaço são os eixos de nossa história, o que implica que a consciência nacional, o ideal comum, seja sua conquista. Ideal comum que já existiu no Brasil, em um período que não se precisa, mas anterior ao liberalismo, o qual fez com que essa consciência comum nacional se perdesse, até que os integralistas a fizessem reviver. O ideal nacional está, assim, inscrito na natureza e é encontrado no passado.

Reale nomeia bandeirismo o ideal que deve ser perseguido no Brasil. O bandeirismo é a conquista da terra, é "a reação permanente do homem contra as forças da Natureza" (REALE, 1934, p. 128). Sua realização exige uma mudança de atitude, da passividade ante às exuberâncias e potências naturais para a atividade de conquista da natureza e do interior (do sertão), isto é, para o imperialismo intrafronteiras. Isso porque "Temos vivido na admiração passiva das magnificências da nossa natureza". A culpa é do liberalismo, que nos desviou do bandeirismo: "O liberalismo no Brasil foi um ato de passividade antes as forças da terra, um desvio do bandeirismo que é a reação permanente do homem contra as forças da natureza" (REALE, 1983-2, p. 91).

A reação bandeirista é a reação da nação brasileira ao liberalismo (e ao capitalismo), é a forma do nacionalismo brasileiro. A "grandeza do integralismo", pois, foi reviver a ideia que deve dirigir a realização do destino nacional:

a grandeza do integralismo consiste em ter revivido o antigo ideal da Nação, conclamando os novos bandeirantes para a conquista da terra e de nós mesmos. É o imperialismo dentro das fronteiras. A tensão espiritual que há de dar ao mundo um tipo novo de civilização, a civilização tropical, cheia de delicadezas e de espiritualidade (REALE, 1934, p. 242).

Para Reale, o grande feito integralista é a fixação da conquista da própria terra como a finalidade comum a ser perseguida. O principal desafio dos brasileiros é a atualização das bandeiras, a realização do 
imperialismo dentro das fronteiras. Esse esforço inaugurará não só um país, mas apresentará ao mundo uma nova civilização, “a civilização tropical”, marcada pela espiritualidade, pela delicadeza, pela docilidade, bondade e ingenuidade de seu povo. O bandeirismo irá "tornar o homem brasileiro tão grande como grande é a terra que conquistou".

\section{A economia do bandeirismo}

Nossas fontes de riqueza, até ontem precárias devido à supremacia do industrialismo do carvão, do ferro e do petróleo, já são reais hoje que a técnica abre novos horizontes ao aproveitamento do minério e das forças hidráulicas, e o homem ouve novamente o chamado da terra fértil./ (...) Reunir as energias nacionais e conduzi-las para a conquista da terra, estendendo a toda a nação um comunalismo semelhante ao das primeiras fazendas; (...) eis o programa que nos deve animar.

Vendo as chaminés que se elevam no céu cinzento dos bairros industriais, é imenso o nosso orgulho.

Nesta época na qual todas as nações, por mais deficientes que sejam de recursos, não poupam esforços no sentido de criar uma indústria própria, é justo que nos orgulhemos do parque industrial brasileiro, de tudo o que já nos foi dado fazer, e do muito que ainda é possível levar a termo.

Miguel Reale

Economicamente, como se põe a aventada conquista da terra?

Antes disso, tem o bandeirismo um programa econômico organizado? Via de regra, não. A matéria é quase sempre abordada de modo difuso, assistemático (notadamente no que tange à esfera da produção) ${ }^{16}$ e também contraditório, ainda que exista um fio condutor. Há uma exceção, veremos adiante, que é o artigo Considerações gerais sobre a indústria brasileira.

Tratemos primeiro de alguns trechos dessa primeira abordagem difusa; trechos significativos, visto que revelam o fio condutor que une as partes de um todo disforme.

Na passagem a seguir, Reale indica que o modo almejado de "nossa afirmação econômica" deve decorrer do bandeirismo, ideal comum que prega a reunião das forças nacionais para a empresa de conquistar a terra em extensão:

Nós recebemos de nossos antepassados o legado de muitos milhões de território. Cumpre-nos conquistá-lo. Nosso

${ }^{16}$ Quanto ao capital financeiro, já vimos, há uma crítica constante e direta. 
imperialismo já tem o objeto. Falta a vontade firme do sujeito dominador, porque nos faltou até agora a consciência de um dever comum./ Sendo possuidores, como somos, de tantas riquezas ainda para explorar, devemos ordenar a nossa economia não somente para criar valores trocáveis, como ensina a escola liberal, mas também para utilizar as forças produtivas./ Neste ponto cabe uma observação que consideramos de grande alcance./ Na Europa, os estados objetivam a organização da vida econômica a fim de se ganhar em intensidade o que não pode mais ser obtido satisfatoriamente em extensão, pelo simples fato de não existirem mais terras incultas ou matérias inaproveitadas. Esta situação é tão grave que a atenção dos técnicos já está voltada para o aproveitamento industrial de determinadas coisas que estavam à margem do ciclo produtivo devido ao seu diminuto rendimento./ Nós, ao contrário, temos terra e temos matériasprimas. Pode ser que não sejamos o mais rico dos países; mas com certeza não somos dos mais pobres./ Se assim é, e se somos poucos, nosso dever é nos organizar para que a energia dos indivíduos não se estanque, mas se propulsione mediante a colaboração dos grupos associados e do estado./ Como escrevi em $O$ estado moderno, ainda estamos no período de desbravamento, no início de uma economia que ainda não se realizou em extensão, nem na realidade, nem nas obras dos cientistas, tão avultado é o número de riquezas ignoradas./ O erro de nossa economia tem sido este, de intensificar a produção de certas riquezas, na exploração descontrolada do açúcar, do café ou do algodão, antes de ter se realizado em extensão. $\mathrm{E}$ todo fracasso de culturas isoladas tem constituído um empecilho ao desenvolvimento de novos setores da economia nacional, em virtude dos déficits acarretados e das quebras previsíveis. (REALE, 1983-3, pp. 232-3)

Terra, matérias-primas, riquezas, forças produtivas: já as "temos"; isto é, "nosso imperialismo" já tem objeto. Falta a vontade do "sujeito dominador" de cultivar, explorar, aproveitar, utilizar. Une-se a vontade do "sujeito dominador" com o objeto do "nosso imperialismo" no cultivo da terra, no aproveitamento das matérias-primas, na utilização das forças produtivas, na exploração das riquezas ignoradas no território brasileiro. Isso é realizar a economia em extensão, conquistar o território nacional, em síntese: implementar o ideal bandeirista.

Se na Europa a economia é voltada à intensificação da produção, visto que a conquista territorial já se completou, aqui, ao contrário, o objetivo fundamental é a conquista da extensão territorial, é a utilização do imenso território desaproveitado, não a intensificação da produção. Se na Europa visa-se ganhar em tempo o que não mais se tem em espaço, intensificando-se a produção, no Brasil, pátria feita de espaço, trata-se 
apenas de se apropriar da ampla terra ${ }^{17}$. Isso implica uma reorientação da economia, que não mais deve ser baseada na intensificação da produção de alguns produtos, como o café, o algodão e o açúcar (o que erroneamente se fez), mas sim na apropriação em extensão da terra.

Eis o “programa que nos deve animar”, isto é, o modo prescrito de atualização econômica do ideal bandeirista:

No Brasil não há apenas uma economia a organizar, mas também uma economia a criar (...). Nossas fontes de riqueza, até ontem precárias devido à supremacia do industrialismo do carvão, do ferro e do petróleo, já são reais hoje, que a técnica abre novos horizontes ao aproveitamento do minério e das forças hidráulicas, e o homem ouve novamente o chamado da terra fértil./ Nossa afirmação econômica implica o problema de valorizar o homem. Não valorização apenas no sentido eugênico e no da especialização técnica, mas sobretudo no sentido de criar um ideal para a nação, de acordar no espírito brasileiro o bandeirismo adormecido entre as fronteiras das províncias. Só assim poderemos aproveitar a potencialidade criadora do sulino desbravador do sertão no plantio do café e do mate, do garimpeiro que reata a mineração do passado, do gaúcho que completa a economia dos trópicos com as suas culturas mediterrâneas, do nordestino que penetra triunfante no labirinto amazônico. Reunir as energias nacionais e conduzilas para a conquista da Terra, estendendo a toda a Nação um comunalismo semelhante ao das primeiras fazendas ${ }^{18}$; fazer 0 homem agir ao lado dos outros homens vencendo a dispersão das distâncias geográficas pela imposição de um mesmo objetivo e de um mesmo plano; aproveitar, na exploração econômica, a capacidade intuitiva de nosso espírito, reforçando, como diz Azevedo Amaral, as faculdades analíticas e discursivas da inteligência; eis o programa que nos deve animar. É imperialismo interior, que parte do domínio do homem sobre si mesmo para o domínio das forças naturais que as fronteiras da pátria delimitam. Temos tudo em nós mesmos e em nossa casa. (REALE,1934, pp. 236-7, grifo meu)

Se "temos tudo em nós mesmos e em nossa casa", o "programa que nos deve animar" é a conquista da terra, o imperialismo interior, visando “[a]o domínio das forças naturais que as fronteiras da pátria delimitam”. A

17 A referência à Europa não é ocasional. Em Reale, a argumentação que justifica a particularidade do integralismo diante do fascismo europeu é desenvolvida a partir do contraponto com a sua apreciação do quadro europeu. É nessa trama teórica que Reale dispõe os fatores (em especial a disparidade entre a população reduzida e o vasto território) que explicam a razão de o patriotismo brasileiro não ter um cunho expansionista (visa à conquista do próprio território).

${ }^{18}$ De se notar que na edição de suas obras pela UnB, em 1983, o trecho está assim escrito: "um comunalismo cristão como já existiu em algumas das primeiras fazendas" (REALE, 1983-2, p. 164, grifo meu). Não sabemos se este acréscimo já constava de outra edição da obra. O intento talvez seja o de afastar qualquer entendimento que aproxime comunal de comunista, daí a aposição do "cristão". 
reunião das energias nacionais para esse fim desabrochará as diversas potencialidades econômicas locais, como o plantio do café e do mate, a mineração, as culturas mediterrâneas, a penetração no labirinto amazônico ${ }^{19}$.

"E o homem ouve novamente o chamado da terra fértil"! Reale vê no progresso da técnica o meio de atender ao chamado da natureza:

Nossas fontes de riqueza, até ontem precárias devido à supremacia do industrialismo do carvão, do ferro e do petróleo, já são reais hoje que a técnica abre novos horizontes ao aproveitamento do minério e das forças hidráulicas, e o homem ouve novamente o chamado da terra fértil. (REALE,1934, pp. 236-7)

Contrasta com o criticado industrialismo (fundado no carvão, no ferro e no petróleo ${ }^{20}$ ) não apenas o aproveitamento do minério e das forças hidráulicas, mas notadamente o atender ao chamado de exploração da terra fértil, terra que é o eixo de nossa história. Terra que, aqui, não quer dizer espaço em geral, mas objeto de cultivo. E como cooperariam esses novos bandeirantes na imensa tarefa de exploração econômica, de conquista da terra, de domínio das forças naturais no interior das fronteiras? Uns "ao lado dos outros", "estendendo a toda a nação um comunalismo [cristão] semelhante ao das primeiras fazendas" ${ }^{21}$.

19 Como vimos, são apenas atividades econômicas primárias e, sobretudo, rurais. Não se fala aqui, e isso é importante, de bens de mais trabalho social acumulado (maior valor agregado, como se diz), como máquinas, trens, caminhões, carros, mas sim em café, mate, culturas mediterrâneas etc.

20 Note-se que carvão, ferro e petróleo eram precisamente as matérias-primas fundamentais ao progresso industrial e à busca por uma "independência econômica" nacional (e é justamente contra o "industrialismo" fundado nessas matérias que se insurge Reale). Veja-se o que dizia Getúlio Vargas sobre essas matérias: "Não temos sido até aqui, mais do que produtores de matérias-primas de origem vegetal e animal. É chegada a oportunidade de abrir caminhos novos e de estruturar o novo progresso sob novos esteios, menos acessíveis às dificuldades que nos venham do exterior. A exploração das riquezas do subsolo e o tratamento industrial dos produtos minerais básicos - carvão, ferro e petróleo - e a criação da metalurgia adiantada são etapas indispensáveis à nossa independência econômica" (apud FRANCO; SILVA; DRUMMOND; TAVARES, 2012, p. 423).

${ }^{21}$ Pretende-se, assim, esse comunalismo cristão semelhante ao das primeiras fazendas. A ideia é, por natureza, de difícil determinação, visto que se remete a tempos, lugares e modos incertos. Ainda assim, o que se pode inferir desse aventado comunalismo, cristão ou não, semelhante ao das primeiras fazendas? Decerto um intento genérico de atualizar um modo de produzir passado, pré-capitalista (anterior ao menos à indústria e à manufatura); também, uma idílica apologia de um modo de produção pré-capitalista, envolto numa ideia algo vaga e mal formada de um trabalho coletivo (ou apenas imediatamente social), exercido em cooperação direta, com rudimentares divisão do trabalho e tecnologia, sem a indicação de instrumentos de produção automáticos (aptos tanto a aliviar a faina diária como a intensificar a exploração do trabalho na produção de valor). Distancia-se, assim, tanto da potencialidade emancipatória da máquina como de sua atualização histórica na exploração capitalista. Isto, aqui, não poderia ser de outro modo, visto que afasta a máquina como meio material de conquista da terra. 
Em outro momento, contraditoriamente, Reale exalta o progresso da técnica e a própria indústria do carvão, do ferro e do petróleo. Diz o seguinte a respeito dela:

Os progressos surpreendentes da técnica e os vultosos gastos exigidos pelos gigantescos empreendimentos modernos, como as estradas de ferro, as indústrias do carvão, do ferro, do petróleo, a aviação mercantil, o comércio em grande escala, a industrialização da agricultura etc. etc., todas essas manifestações prodigiosas do gênio criador. (REALE, 1983-2, p. 216)

Aqui exalta, porém, no contexto da obra ( $O$ capitalismo internacional - introdução à economia nova), apenas como um introito para uma crítica das sociedades anônimas (REALE, 1983-2, pp. 216-8). Muitas vezes assim considera a indústria: se exalta algum aspecto positivo é para o fim de o contrapor a um outro - predominante - aspecto negativo.

Tanto é assim que antes os "esplendores" das indústrias já apareceram para lembrar que elas não são suficientes para conformar uma nação (pois o que importa é um ideal comum):

Não bastam também estradas de ferro, rodovias, linhas aéreas, rádios, telégrafos, comércio interno. Não bastam a força e a glória dos exércitos e das esquadras. Não basta a unidade da língua e a semelhança das religiões. Não basta o esplendor das indústrias e as afirmações maravilhosas da ciência. Não bastam as divinas criações da arte. Consciência nacional existe onde há esses fatores todos e outros mais, desde que de geração em geração se transmita o culto dos grandes homens, o orgulho pelo que se fez e a certeza de que é possível fazer mais. Consciência nacional existe onde há memória, presença do passado como estímulo do presente, ou seja, a unidade da tradição. (REALE, 1983-1, p. 81)

Já quando aborda as consequências da "segunda revolução industrial" (a eletricidade), o aspecto positivo da indústria é que permite um idealizado "equilíbrio" entre cidade e campo (pois implica descentralização econômica, não exige êxodo rural). Daí que: "O progresso da técnica, as conquistas da ciência permitem voltar a um regime de vida que parecia destruído pelas cidades tentaculares...” (REALE, 1983-2, p. $215)^{22}$

"Nossas" cidades resistem às investidas cosmopolitas. Persistem hábitos, celebrações e sua alegria ingênua:

22 Aqui, como vemos, Reale elogia o desenvolvimento da técnica e da ciência; todavia, o faz sob o ponto de vista de sua contribuição ao regresso a um modo de vida não marcado pelos efeitos dissolutores da expansão das cidades, que desfaziam um regime de vida estável e harmônico, o que seria marca forte das cidades brasileiras. 
As cidades são iguais. Com os mesmos costumes, as mesmas festas, a mesma capacidade de ser ingenuamente alegres (...). A semelhança das cidades brasileiras é das coisas que mais surpreendem os que percorrem o Brasil. Plínio Salgado sente, na sua sensibilidade de artista e de político, o que representa esse fato que tem resistido a tudo como um tesouro à margem das investidas cosmopolitas. (REALE, 1983-3, p. 147)

As cidades existentes devem resistir às investidas cosmopolitas, às cidades tentaculares. Não obstante, o bandeirismo demanda mais e novas cidades: a "multiplicação das cidades na conquista progressiva da terra, como centros de ligação cada vez mais estáveis, mais apegados à terra”. A conquista da terra demanda, assim, a multiplicação das cidades, não de um modo de vida cosmopolita, mas de cidades enquanto centros de ligação estáveis e apegados à terra. Cidades que não são subjugadas por cidades tentaculares, que resistem às investidas cosmopolitas, que preservam modos de vida antigos.

Assim se dá, de regra, a abordagem de Reale acerca da produção (industrial e agrícola) e de seus efeitos no modo de vida. A ênfase é conferida à agricultura, ao cultivo da terra; a indústria surge geralmente como algo secundário. Já mencionamos que, quando exalta um lado positivo da indústria, isso é feito como um preâmbulo a uma crítica a um outro aspecto econômico predominantemente negativo (como as sociedades anônimas e a ausência de um ideal comum), ou então para afirmar uma possibilidade de regressão que ela oferece (como no caso das cidades).

Portanto, é raro, inclusive pelo genérico teor passadista, um trato objetivo e coerente da matéria, o que lhe tocou fazer, excepcionalmente, no ensaio Considerações gerais da indústria brasileira, que se aproxima de uma proposta de política econômica. Nele, Reale assume mais uma postura de quem se pretende homem de estado, a quem cumpre lidar com problemas concretos, postos da maneira que estão e não de acordo com a sua imaginação, situação que o força a aquiescer com elementos da realidade, como a indústria.

Nesse ensaio, inserido na obra Atualidades brasileiras (1937), Reale exprime seu diagnóstico e seu projeto para a indústria nacional. Postula uma revisão das tarifas aduaneiras, de modo que as indústrias nacionais sejam protegidas apenas na medida do necessário para concorrer com o capital estrangeiro. Ele verifica uma utilização abusiva dessas tarifas de proteção, circunstância que, somada à depreciação cambial, além de criar barreiras à importação, permitiria (em razão da ausência de coordenação do estado) o pagamento de baixos salários e a alta de preços. Isso resultaria em queda do consumo, prejudicando, além dos consumidores, também os "produtores", de modo que defende o estabelecimento de um 
salário mínimo, no interior de uma perspectiva de conciliação dos interesses das classes sociais. O central deste artigo é a defesa da coordenação da economia em geral, e da política industrial em particular, pelo estado, o que implicaria principalmente a revisão geral da tarifação aduaneira, sem prejuízo de outras medidas, como uma espacialização regional planejada da indústria e a fixação de um salário mínimo, tudo disposto no seio de uma estrutura corporativa de estado ${ }^{23}$.

Além da novidade de apresentar um programa econômico minimamente estruturado, voltado à "racionalização industrial", Reale diverge dos que afirmam a vocação essencialmente agrícola do país, sustentando a necessidade de compatibilizar o desenvolvimento industrial com o agrícola.

Clama pela formulação de uma primeira política industrial no Brasil, já que a indústria aqui, como as outras atividades, desenvolveu-se de modo anárquico. Defende melhorias no "aparelhamento técnico" e a racionalização de sua organização, visando a aumentar a "intensidade produtiva”. A indústria não mais deve ser baseada nos baixos salários e em proteções aduaneiras permanentes. Não se pode compensar a falta de organização racional e o aparelhamento técnico medíocre com os baixos salários, pois "o mal do operariado mais cedo ou mais tarde é mal do patrão” (REALE, 1983-3, p. 139). Vejamos:

Em comparação com as indústrias europeias e americanas do Norte, é evidente a nossa pobreza técnica, e não menos irrisórias as condições de nossa organização quase que totalmente empírica, desarticulada, desracionalizada." (REALE, 1983-3, p. 128)

Para sairmos dessa situação, impõe-se em primeiro lugar a fixação de um plano racionalizador de nossas atividades industriais. (REALE, 1983-3, p. 128)

A indústria brasileira surgiu sem orientação, desarticulada, obedecendo tão somente aos cálculos pessoais de cada capitalista (...). Ainda não houve no Brasil uma política de orientação industrial. Por enquanto só tivemos medidas isoladas e desconexas de protecionismo aduaneiro, que nunca foi entendido, infelizmente, como capítulo inicial de um plano geral de industrialização, mas sim como simples providência

23 "O que é necessário é que o governo trace um programa de ação (...). É claro que nada se poderá fazer nesse sentido enquanto perdurar o atual regime econômico que faz do capital o princípio e o fim da economia./ Somente nos quadros da economia corporativa, o interesse individual se porá em harmonia com o interesse coletivo, passando o capital a ser empregado de acordo com as exigências totais da sociedade e as particularidades do capitalista./ Hoje em dia o capital pode ser utilizado onde, como, quando e quanto quer o seu proprietário, que é livre de manejá-lo a seu bel-prazer, sejam quais forem as consequências de seus atos para com a produção nacional./ No estado integralista, ao contrário, as indústrias terão que obedecer aos planos traçados pelos próprios industriais reunidos em suas instituições de classe, planos esses, em seguida, discutidos e aprovados pelas demais corporações não-industriais.” (REALE, 1983-3, p. 137) 
isolada./ O problema industrial brasileiro tem tal relevância que urge criar as situações indispensáveis ao seu mais rápido e orgânico desenvolvimento, prevendo as funestas consequências do atual estado de coisas. (REALE, 1983-3, p. 129)

Não basta pregar a industrialização, é preciso que a industrialização se pregue como um capítulo da economia e da política nacionais (...). (REALE, 1983-3, p. 136)

A indústria aumentou "nosso" potencial econômico, tornou-nos "independentes", permitiu que enfrentássemos os efeitos da crise de 1929 e é, inclusive, condição da unidade nacional. O estado deve incentivar e salvaguardar as indústrias nacionais promissoras e que ainda não tenham condição para a concorrência com as estrangeiras; deve garantir auxílio financeiro, criar escolas e faculdades técnicas.

O que importa - e é o que este estudo deixa em evidência - é que o problema industrial seja posto no quadro geral da economia brasileira, integrado no sistema nacional de nossas atividades produtoras, sem os perigos incalculáveis de um desenvolvimento anárquico e unilateral que poderia vir a ser o caminho do aniquilamento do estado e o instrumento certo da desagregação da pátria. (REALE, 1983-3, p. 141)

Vencemos com certo desafogo esse longo período de crise mundial, precisamente porque possuímos um parque industrial próprio, o que deu incremento ao nosso comércio interno, pondo, portanto, mais em contato as unidades da federação. (REALE, 1983-3, p. 133)

(...) certas indústrias (...) não têm se preocupado com a organização racionalizada nem com o aparelhamento técnico exigidos no mundo moderno, continuando - como no século passado - a viver do que Marx chamou de "mais-valia", o que quer dizer, mediante a política retrógrada de aumentar os lucros à custa dos que cooperam nas riquezas (REALE, 1983-3, p. 139). Felizmente, parece que uma nova mentalidade vai se formando (...). Até que enfim vão percebendo que o mal do operariado mais cedo ou mais tarde é mal do patrão. (REALE, 1983-3, p. 139)

Aponta que o Brasil pode receber investimentos estrangeiros, mas esse deve ser fiscalizado e aplicado produtivamente, não para criar dívidas. (REALE, 1983-3, p. 141)

Além do mais, o estado deve cuidar do auxílio direto das indústrias promissoras, incrementando o conhecimento de nossas imensas riquezas, criando escolas e faculdades técnicas, transformando a organização bancária em verdadeiro coração da economia, abastecendo os produtores nacionais de recursos indispensáveis. (REALE, 1983-3, p. 141)

O "problema industrial" deve ser equacionado, acrescenta, no quadro geral da economia nacional, junto do comércio e da agricultura. Erram, assim, os cantores do país fatalmente agrícola, pois indústria e agricultura são valores produtivos complementares, que não se opõem e 
são igualmente essenciais, tanto que, salienta, a mais industrial das unidades da federação, São Paulo, é também a mais agrícola. Afirmar uma vocação essencialmente agrícola implica que nos contentemos sempre com o papel de fornecedores de matérias-primas:

Com o aparecimento da indústria nacional, muitíssimas riquezas passaram a ser aproveitadas. Elevou-se o nosso potencial econômico. Tornamo-nos, de certa forma, independentes. Deixamos de ser "essencialmente agrícolas" para começarmos a compreender que possuímos condições $e$ meios de um país tanto industrial como agrícola. Nossa atividade deve se desenvolver em todos os sentidos, completando-se como se completam os recursos das várias regiões do Brasil. (REALE, 1983-3, p. 132, grifo meu)

De início, lembremos que não é possível resolver o problema da indústria a não ser no sistema global de todas as nossas atividades econômicas. Seccioná-lo da agricultura e do comércio seria cair num erro gravíssimo. (REALE, 1983-3, p. 129)

Mencionando que "lavradores" e "industriais" estão "em fase ascensional" em SP, ele argumenta:

Como se vê [apresentou dados], equivalem-se essas forças de tal sorte que a mais agrícola das unidades da Federação [SP] é também a mais industrial. O que nos cumpre fazer é assegurar essa correspondência de valores produtivos, dando à economia brasileira a saúde que resulta sempre de um harmônico desdobramento das fontes de riqueza. (REALE, 1983-3, p. 130)

(...) os países jovens (...) possuem riquezas a explorar, e (...) não podem continuar sempre no papel de fornecedores de matérias-primas (REALE, 1983-3, p. 132, grifo meu).

(...) uma atividade depende de outra (...) o progresso de uma condiciona o progresso da outra (REALE, 1983-3, p. 130, grifo meu).

Para os cantores do país essencialmente agrícola, devíamos ter continuado a ser uma Nação fornecedora de matériasprimas, sempre à mercê das altas e baixas dos centros industriais estrangeiros. (REALE, 1983-3, p. 131)

Não é exagero dizer que da estabilidade de nossas indústrias, depende, em grande parte, a unidade nacional. Com efeito, a saúde de nossa economia só poderá ser uma consequência de uma perfeita consonância entre a nossa agricultura e a nossa indústria. (REALE, 1983-3, p. 133)

\section{Pequenos proprietários: a classe revolucionária}

A sociedade política é, pois, garantida especialmente pelos cidadãos de fortuna média.

Quando os homens da classe média perdem a sua posição social e econômica, dá-se uma revolução, que pode se processar tanto na linha do desespero bolchevista como no sentido orgânico do integralismo.

Miguel Reale 
Revolução é a assunção, mediada por um golpe, do ideal comum nacional pelo estado 24 . A revolução integralista é a assunção do ideal bandeirista ao estado. A classe social portadora da ideia revolucionária e responsável pela empresa revolucionária é a dos pequenos proprietários.

Reale, aliás, deixa claro que é a perspectiva dos cidadãos de fortuna média, da classe média, dos capitais pequenos (termos que emprega como sinônimos), que busca vocalizar.

Daí que diga que é preciso fortalecer a classe média, pois ela é a classe social portadora da ideia revolucionária:

Com a destruição direta ou indireta dos capitais pequenos, há um declínio na classe média, classe sofredora de cujo seio fecundo - em que se sintetizam os valores e os sofrimentos das duas outras- têm saído as mais, em todos os tempos, as mais altas expressões do gênio. É essa classe que faz a revolução, porque é ela que é portadora da ideia. As outras camadas sociais, as superiores e as inferiores, recebem dela a seiva vivificadora, mas as últimas sobem de mãos dadas com ela./ Quando os homens da classe média perdem a sua posição social e econômica, dá-se uma revolução, que pode se processar tanto na linha do desespero bolchevista como no sentido orgânico do integralismo. (REALE, 1983-2, pp. 225-6)

Neste trecho, Reale enuncia sob qual ponto de vista escreve e a classe social cujos interesses pretende organizar e fazer ascender. São os capitais pequenos, a classe média, os portadores da "ideia". Isso porque é a classe que é síntese de todas as classes, amálgama dos "valores e sofrimentos das duas outras", da "superior" e da "inferior", isto é, do capital e do trabalho. É ela, portanto, a classe que guia a revolução e que dirigirá a sociedade política.

A revolução tem por causa a perda da sua "posição social e econômica" 25 e, para que não degenere na forma bolchevista, deve ser conduzida conforme o sentido orgânico do integralismo, isto é, de conciliação de classes no interior da estrutura do estado.

Reale, então, colocando-se como porta-voz dos capitais pequenos, arremata: "O destino de um país depende sempre da cultura e dos sentimentos dos que exprimem as aspirações e as revoltas da classe média.” (REALE, 1983-2, p. 226)

$24 \mathrm{O}$ estado integral é o "estado soberano que assegura a si próprio o direito de dirigir a revolução" (REALE, 1983-3, p. 220) e "Toda revolução se dissolve na anarquia, na ruína total, se não encontra o seu 18 Brumário. O 18 Brumário não é um golpe de morte sobre a Revolução, é a própria revolução que encontrou seu centro de equilíbrio" (SALGADO apud REALE, 1934, p. 173).

25 É o caso dos pequenos proprietários agrícolas, endividados com os possuidores indiretos (os bancos) e assim são explorados pelo banqueirismo internacional (REALE, 1983-2, pp. 213-4). 


\section{Conclusão}

Concebendo a história como união entre ser e dever-ser, ou entre natureza e liberdade, e colocando a sociedade na parte da natureza e o estado na parte da liberdade, Reale pretende que o estado imponha uma finalidade para uma sociedade anômica, a sociedade liberal. O estado impõe uma finalidade à sociedade quando se identifica com a nação, que é síntese comum de querer, ideal comum. Chama de revolução a assunção do ideal nacional ao nível do estado, mediada por um golpe.

O capitalismo financeiro (o "superestado-transnacionalcapitalista"), porém, domina os estados e impede que se identifiquem com a nação. É preciso subordinar a economia à moral nacional encarnada no agir estatal. O nacionalismo anticapitalista prega a revolução da pátria contra o capitalismo (na forma de capitalismo financeiro), impondo à economia o ideal próprio de cada nação. Tal é, para Reale, a característica fundamental do fascismo. Fascismo, para ele, é um movimento que prega "governos fortes" que impõem uma finalidade nacional à sociedade liberal. Reale identifica o integralismo com o fascismo enquanto movimentos, diz ele, nacionalistas, anticapitalistas e anti-imperialistas.

É nesse sentido que Reale, sem prejuízo de afirmar a "brasilidade da nossa doutrina" (REALE, 1983-3, p. 65), põe o integralismo como uma resultante particular da universalização do fascismo (REALE, 1983-3, p. 209), concebido este como o movimento de reerguimento das pátrias contra o capitalismo, não por obra de uma classe, mas por obra de uma nação ${ }^{26}$.

Entretanto, no Brasil há um obstáculo preliminar: o ideal nacional ainda não foi revelado, não se disse ainda "quero ser isto!". O objeto desse querer deve ser extraído do passado. Descobre, então, na terra o eixo de nossa história e na sua conquista o ideal nacional a ser efetivado pelo estado. É o ideal bandeirante, que prega a conquista da própria terra (o imperialismo entre fronteiras). Logo, não se pretende dominar outros países militarmente nem economicamente (distinção essencial quanto ao fascismo e ao nazismo), o objetivo é conquistar a terra própria; esse será o papel histórico do Brasil, que entregará "ao mundo um tipo novo de civilização, a civilização tropical, cheia de delicadezas e de espiritualidade" (REALE, 1934, p. 242).

Assim, é o bandeirismo o imperativo moral que, encarnado no estado integral, deve guiar a economia nativa. É via de eliminação da luta de classes e promoção da solidariedade social por meio de um

26 Noutro momento, ele assemelha os "movimentos políticos integrais" de Itália, Alemanha, Portugal e Brasil pelo fator da "identificação perfeita entre chefia e doutrina" (REALE, 1983-3, p. 250). 
corporativismo político, que faz de todos igualmente membros do estado e, portanto, elos da realização do ideal comum, logo, elos da realização do bandeirismo. O ideal bandeirista, saliente-se, é o ponto de chegada do integralismo de Miguel Reale. Todas as vertentes de seu pensamento desaguam nele, que concentra todas elas.

Quando analisou o integralismo de Plínio Salgado, J. Chasin encontrou limites teleológicos, caracterizados por uma regressividade mínima e por uma regressividade máxima ${ }^{27}$. Em Reale, esses limites teleológicos mínimo e máximo também existem (com uma figuração própria) e são ambos orientados pela regressividade e pelo nacionalismo defensivo (negação do expansionismo). Transitam do chamado da terra fértil e da defesa de espalhar pelo país um "comunalismo cristão semelhante ao das primeiras fazendas" até, excepcionalmente, uma proposta de política industrial e a refutação da ideia de um país fatalmente agrícola.

A análise imanente do integralismo realiano permite corroborar a tese fundamental de Chasin (n'O integralismo de Plínio Salgado: forma de regressividade no capitalismo híper-tardio), autêntico "divisor de águas" na historiografia do integralismo, segundo a qual "Ontológica e teleologicamente, fascismo e integralismo se põem como objetivações distintas" (CHASIN apud RAGO, 2008, p. 212). Sumariamente, pode-se dizer que a situação histórica a que responde o integralismo e a própria resposta integralista, enquanto tomada de consciência voltada à atuação prática, são diferentes em relação tanto à trama social de que emergiu o fascismo como no que diz respeito à sua própria estrutura conceitual.

Analisando um objeto distinto, o integralismo de Gustavo Barroso, Antonio Rago Filho distinguiu o "nacionalismo defensivo" dos integralistas do expansionismo nazi-fascista, chegando a conclusão semelhante ${ }^{28}$. Não se trata, por óbvio, de impor uma mesma fôrma a matérias diversas. Ao contrário, trata-se do fato de que a análise de um específico objeto (aqui, o integralismo de Miguel Reale) permite corroborar a validade geral da conclusão, anteriormente posta por Chasin e Rago, de que não há identidade entre fascismo e integralismo.

27 "Chasin divisa os dois limites teleológicos da oposição romântica à miséria brasileira, que escaparam inteiramente à versão hegemônica do integralismo, a saber: 'o limite máximo, que designamos por utopia reacionária ou regressiva, que visiona a conversão do país numa pletora de pequenas propriedades, quase que exclusivamente rurais, e que, pela sua total inviabilidade, e até mesmo absurdidade, jamais é inteiramente explicitada. O limite mínimo, também de solução ruralista, mas que, por assim dizer, se conforma em transigir um pouco, busca pelo menos frear ou estancar a acumulação capitalista"” (RAGO, 2008, p. 204).

28 "A crítica imanente do conjunto das obras de Barroso, particularmente, no período de sua franca atuação entre 1933 e 1938, mesmo com o nódulo ideológico do antissemitismo, revela a mesma identidade do nacionalismo defensivo nascido nos contornos da via colonial de objetivação capitalista" (RAGO, 2008, p. 212). 
Uma suma da distinção, aliás, foi rigorosamente disposta por Chasin:

o fascismo é uma ideologia de mobilização nacional para a guerra imperialista, que se põe nas formações de capitalismo tardio, quando estes emergem na condição de elos débeis da cadeia imperialista, e o integralismo, uma manifestação de regressividade nas formações de capitalismo híper-tardio, uma proposta de frenagem do desenvolvimento das forças produtivas, com um apelo ruralista, no preciso momento em que estas principiam a objetivar o "capitalismo verdadeiro" (CHASIN, 1978, p. 647).

Ainda que apenas no âmbito do ideário, a diferença é francamente nítida. No entanto, infelizmente, a despeito de superada, a ideia do mimetismo ideológico do fascismo pelo integralismo reina pelos ares, mesmo que por dentro desmontada29.

Para finalizar, indicando o disparate da identificação entre o integralismo e o fascismo, apresentamos um quadro comparativo (abaixo) de dizeres significativos do integralista Miguel Reale e do ditador fascista Benito Mussolini, a fim de expor, sumariamente, a cabal diferença entre os ideários, pois ambos, como diz Chasin, devem ser condenados sempre "por aquilo que são":

\begin{tabular}{|c|c|}
\hline Miguel Reale & Benito Mussolini \\
\hline $\begin{array}{l}\text { “(..) a grandeza do integralismo consiste } \\
\text { em ter revivido o antigo ideal da nação, } \\
\text { conclamando os novos bandeirantes para a } \\
\text { conquista da terra e de nós mesmos. É o } \\
\text { imperialismo dentro das fronteiras. A } \\
\text { tensão espiritual que há de dar ao mundo } \\
\text { um tipo novo de civilização, a civilização } \\
\text { tropical, cheia de delicadezas e de } \\
\text { espiritualidade." (REALE, 1934, p. 242) } \\
\text { "(...) nosso patriotismo não agride...” } \\
\text { (REALE, 1983-3, p. 149). } \\
\text { "Temos tudo em nós mesmos e em nossa } \\
\text { casa." (REALE, 1934, p. 237) } \\
\text { "Temos em relação à Europa duas }\end{array}$ & $\begin{array}{l}\text { "Uma nação, como expressa no estado, é } \\
\text { uma entidade viva e ética apenas na medida } \\
\text { em que é ativa. Inatividade é morte. Por } \\
\text { isso, o estado não é apenas a autoridade que } \\
\text { governa e confere forma legal e valor } \\
\text { espiritual às vontades individuais, mas } \\
\text { também o poder que faz sentir e ser } \\
\text { respeitada a sua vontade para além das } \\
\text { próprias fronteiras, assim fornecendo prova } \\
\text { prática da natureza universal das decisões } \\
\text { necessárias para garantir seu } \\
\text { desenvolvimento. Isso implica organização } \\
\text { e expansão potenciais, se não reais. Assim o } \\
\text { estado se iguala à vontade do homem, cujo } \\
\text { desenvolvimento não pode ser impedido }\end{array}$ \\
\hline
\end{tabular}

29 Um exemplo atual do equívoco é a tese de Pedro Ivo Dias Tanagino ( $A$ síntese integral: a teoria do integralismo na obra de Miguel Reale [1932-1939]), que se propõe a analisar "a performance linguística individual" (pp. $7 ; 176$ ) de Miguel Reale, em uma abordagem "linguística e contextualista" (p. 38), fundada em autores como Pocock e Saussure. Segue sua conclusão: "Seguindo a tese clássica de Hélgio Trindade, tratamos aqui o integralismo como um 'fascismo brasileiro"” (p. 357); "trataremos o nosso objeto de análise ao longo de toda essa investigação como uma cultura política fascista” (fls. 31). 


\begin{tabular}{|l|}
\hline superioridades: temos terra em \\
abundância, não lutamos com angústias de \\
espaço, nem sentimos a imperiosa \\
necessidade de conquistar domínios; em \\
segundo lugar, temos poucos \\
compromissos ou contas a saldar, uma \\
herança quase nula de ódios ou \\
ressentimentos, de uma vida restrita no \\
tempo./ O nacionalismo da Europa vive de \\
desconfianças, de agressões, na previsão \\
enervante de surpresas bélicas. Nós \\
podemos e devemos ser nacionalistas, sem \\
ser preciso fundamentar a nossa união no \\
ódio ou no receio." (REALE, 1983-3, p. \\
231)
\end{tabular}
231) por obstáculos e que, ao adquirir
autoexpressão, demonstra sua infinitude"
(MUSSOLINI, 2019, p. 19)

“O fascismo não crê, de maneira geral, na possibilidade ou utilidade da paz perpétua. Assim, ele descarta o pacifismo como um manto para renúncia covarde e complacente, em contraste com o autossacrifício. Somente a guerra leva toda a energia humana à sua tensão máxima e apõe o selo da nobreza naqueles povos que têm a coragem de encará-la. Todos os demais testes são substitutos que jamais porão o homem cara a cara consigo mesmo diante da alternativa de vida ou morte. Por isso, todas as doutrinas que postulam a paz a qualquer custo são incompatíveis com o fascismo." (MUSSOLINI, 2019, p. 24)

"O estado fascista expressa a vontade de exercer poder e comandar. Aqui a tradição romana está incorporada numa concepção de força. O poder imperial, conforme o entende a doutrina fascista, não é apenas territorial ou militar ou comercial, também é espiritual e ético. Uma nação imperial significa uma nação que direta ou indiretamente lidera as outras, capaz de existir sem necessidade de conquistar um metro quadrado de território. O fascismo vê no espírito imperialista - i.e., na tendência das nações a se expandir - uma manifestação de sua vitalidade. $\mathrm{Na}$ tendência oposta, que limitaria seus interesses ao país natal, vê um sintoma de decadência. Povos ascendem ou reascendem; a renúncia é característica de povos moribundos." (MUSSOLINI, 2019, p. 37)

"Acredito que, se um povo almejar viver, deve desenvolver um desejo de poder. Do contrário, ele vegeta, vive miseravelmente e se torna presa de um povo mais forte, no qual esse desejo de poder se desenvolveu em grau maior." (MUSSOLINI, 2019, p. 50)

"Não existe maneira de exercer influência espiritual no mundo tendo-se uma vontade humana dominando a vontade alheia a 


\begin{tabular}{|c|c|}
\hline & $\begin{array}{l}\text { menos que se tenha uma concepção tanto } \\
\text { de transitoriedade quanto da realidade } \\
\text { específica em que essa ação será exercida, } \\
\text { bem como da realidade permanente e } \\
\text { universal em que o transitório reside e tem } \\
\text { sua essência." (MUSSOLINI, 2019, p. 13) }\end{array}$ \\
\hline $\begin{array}{l}\text { "A nossa terra é linda porque o homem } \\
\text { tem bondade e doçura no coração./ Somos } \\
\text { um povo que não é triste, como dizem. É } \\
\text { ingênuo e moroso, delicado e sentimental." } \\
\text { (REALE, 1983-3, p. 146) } \\
\text { "As cidades são iguais. Com os mesmos } \\
\text { costumes, as mesmas festas, a mesma } \\
\text { capacidade de ser ingenuamente alegres } \\
\text { (...). A semelhança das cidades brasileiras é } \\
\text { das coisas que mais surpreendem os que } \\
\text { percorrem o Brasil." (REALE, 1983-3, p. } \\
\text { 147) }\end{array}$ & $\begin{array}{l}\text { "O fascismo vê no mundo (...) indivíduos e } \\
\text { gerações unidos por uma lei moral, com } \\
\text { tradições em comum e uma missão que, } \\
\text { suprimindo o instinto de vida preso em um } \\
\text { reduzido círculo de prazer, constrói uma } \\
\text { vida mais nobre, fundada no dever, uma } \\
\text { vida liberta das limitações de tempo e } \\
\text { espaço, em que o indivíduo, por meio } \\
\text { do autossacrifício, da renúncia ao interesse } \\
\text { particular, da própria morte, é capaz de } \\
\text { atingir aquela existência puramente } \\
\text { espiritual na qual reside seu valor como } \\
\text { homem. } \\
\text { O fascismo concebe a vida como uma luta." } \\
\text { (MUSSOLINI, 2019, p. 14) } \\
\text { "Quando recentemente um filósofo } \\
\text { finlandês me pediu que esclarecesse o } \\
\text { significado do fascismo em uma frase, } \\
\text { escrevi em alemão: "Somos contra a 'vida } \\
\text { fácil'!" (MUSSOLINI, 2019, p. } 43 \text { ) } \\
\text { "Na origem de tudo está a luta, pois a vida é } \\
\text { cheia de contrastes: existe amor e ódio, } \\
\text { branco e preto, dia e noite, bem e mal, e até } \\
\text { que esses contrastes se equilibrem a luta } \\
\text { está fadada a continuar na raiz da natureza } \\
\text { humana. No entanto, é bom que seja assim. } \\
\text { Hoje podemos nos dar ao luxo de ter } \\
\text { guerras, batalha econômicas, conflitos de } \\
\text { ideias, mas se um dia a luta deixasse de } \\
\text { existir, a melancolia se instalaria; esse seria } \\
\text { um dia de ruína, um dia de desfecho. Mas } \\
\text { tal dia não chegará nunca." (MUSSOLINI, } \\
2019 \text {, p. } 42 \text { ) }\end{array}$ \\
\hline
\end{tabular}




\section{Referências bibliográficas}

ARAÚJO, Ricardo Benzaquen de. In medio virtus: uma análise da obra integralista de Miguel Reale. Rio de Janeiro: Centro de Pesquisa e Documentação de História Contemporânea do Brasil, 1988.

BERTONHA, João Fábio. O pensamento corporativo em Miguel Reale: leituras do fascismo italiano no integralismo brasileiro. Rev. Bras. Hist., São Paulo, v. 33, n. 66, pp. 269-6, 2013.

CHASIN, José. O integralismo de Plínio Salgado: forma de regressividade no capitalismo híper-tardio. São Paulo: Ciências Humanas, 1978.

DIAS TANAGINO, Pedro Ivo. A síntese integral: a teoria do integralismo na obra de Miguel Reale (1932-1939). Tese (Doutorado) defendida na Universidade Federal de Juiz de Fora, Juiz de Fora, 2018.

FRANCO, José Luiz de Andrade; SILVA, Sandro Dutra; DRUMMOND, José Augusto; TAVARES, Giovana Galvão. História Ambiental: fronteiras, recursos naturais e conservação da natureza. Rio de Janeiro: Garamond, 2012.

MAFFEI, Eduardo. A Batalha da Praça da Sé. Rio de Janeiro: Philobiblion, 1984.

MAIOLINI REBELLO PINHO, Rodrigo. Miguel Reale: política e história (1931-1969). Dissertação (Mestrado) apresentada à Pontifícia Universidade Católica de São Paulo, São Paulo, 2008.

MELO, Manuel Palácios Cunha. O integralismo de Miguel Reale. Dados, Rio de Janeiro, v. 37, n. 1, pp. 125-52, 1994.

MUSSOLINI, Benito; TRÓTSKY, Leon. Fascismo - o que é e como combatê-lo. Rio de Janeiro: Nova Fronteira, 2019.

PINHEIRO RAMOS, Alexandre. $O$ integralismo entre a família e o estado: uma análise dos integralismos de Plínio Salgado e Miguel Reale (1932-1937). Dissertação (Mestrado) apresentada à Universidade do Estado do Rio de Janeiro, Rio de Janeiro, 2008.

RAGO FILHO, Antonio. J. Chasin: a crítica ontológica do anticapitalismo romântico típico da "Via Colonial" - os integralismos. Verinotio - Revista on-line de Filosofia e Ciências Humanas, n. 9, ano V, nov. 2008, pp. 187220.

REALE, Miguel. O estado moderno: liberalismo, fascismo, integralismo. Rio de Janeiro: José Olympio, 1934.

- Obras Políticas: $1^{\text {a }}$ fase $-1931 / 1937$. Brasília: Editora Universidade de Brasília, 1983. 3v.

. Memórias v. 1: destinos cruzados. 2. ed. rev. São Paulo: Saraiva, 1987.

. Perspectivas Integralistas. São Paulo: Odeon, s/d.RODRIGUES, Athanis Molás. Raízes integralistas da Teoria Tridimensional do Direito: 
história das ideias de Miguel Reale (1933-1953). Dissertação (Mestrado) apresentada à Universidade Federal de Santa Catarina, Florianópolis, 2014 .

Como citar:

PINHO, Rodrigo Maiolini Rebello. O pensamento integralista de Miguel Reale. Verinotio - Revista on-line de Filosofia e Ciências Humanas, Rio das Ostras, v. 25, n. 2, pp. 331-363, nov. 2019.

Data do envio: 14 jun. 2019

Data do aceite: 16 out. 2019 